DOI https://doi.org/10.32782/2305-9389/2020.22.03

УДК 908(477.65)«18»(092)Левитський

Житков Олександр,

доктор історичних наук, доцент,

дочент кафедри історії України

Центральноукраїнського державного педагогічного університету

імені Володимира Винниченка

\title{
ФОРМУВАННЯ СУСПІЛЬНО-ПОЛІТИЧНИХ ПОГЛЯДІВ УКРАЇНСЬКОГО КООПЕРАТОРА МИКОЛИ ЛЕВИТСЬКОГО В ПЕРІОД 1890-Х - ПОЧАТКУ 1900-Х РОКІВ
}

У статті аналізується проблема формування соиіально-економічних та політичних поглядів громадського діяча, відомого украӥнського кооператора Миколи Васильовича Левитського (1859-1936). 3важаючи на внесок у розвиток теорї кооперації та міжнародний кооперативний рух, практичну діяльність зі створення кооперативів у Херсонській губернї Російської імперії, сучасники називали М. Левитського "кооперативним батьком».

Автором акцентується увага на вивченні впливу на свідомість Миколи Левитського окремих викладачів Златопільської прогімназї Чигиринського повіту Київської губернії, які дотримувалися прогресивних суспільних поглядів, висвітлюється його спілкування з видатними представниками українського письменства, такими як Іван Франко, Леся Украӥнка, Іван Карпенко-Карий.

На основі аналізу наукової літератури та архівних джерел автором публікації обтрунтовано думку, шзо суспільно-політичні погляди М. Левитського розвивалися у середовищі української інтелігенції м. Слисаветграду, яка сповідувала народницькі ідеали. Знання, здобуті в прогімназії, самоосвіта юнака, особливо щчоденне спостереження за трансформаціями селянського господарства у пореформеному украӥнському селі, дали поштовх до практичного застосування набутих М. Левитським теоретичних знань. Домінантою його діяльності y «єлисаветградський період» було обтрунтування економічної доиільності й необхідності створення місиевими селянами виробничих кооперативів із метою протистояння експлуатації селянського дрібного господарства в умовах формування капіталістичного ринку.

Зазначаються здобутки й невдачі «артільного батька» у створенні перших кооперативних об'єднань, розкривається ставлення до иієї справи селян, висвітлюються оцінки внеску М. Левитського у розвиток українського кооперативного руху в Наддніпрянщині на межі XIX-XX століть.

Ключові слова: Микола Васильович Левитський, громадська справа, українофіли, селянство, виробнича кооперація, кооперативна діяльність, м. Златопіль, м. Слисаветград, Херсонська губернія, Російська імперія.

\section{Zhytkov Oleksandr. Formation of the social and political views of the Ukrainian cooperator Volodymyr Levytskyi in the 1890s - early 1900s}

The paper dwells on the issue of the social, economic and political views formation with an outstanding Ukrainian cooperator and public person Mykola Levytskyi (1859-1936) whose contemporaries believed him to be "the father of cooperative movement" because he started the cooperative movement in the Kherson Province of the Russian Empire and made a considerable input in the cooperation theory development as well as international cooperative movement.

The author also highlights the influence of some teachers Mykola Levytskyi had when he studied in Zlatopol Progymnasium of the Chigirin District in the Kiev Province, particularly of those ones who promoted progressive social views. Mykola Levytskyi's communication with famous Ukrainian writers such as Ivan Franko, Lesia Ukrainka and Ivan Karpenko-Karyi has also been given attention to.

The author covers and analyses considerable scholarship as well as archival sources to claim that social and political views of Mykola Levytskyi developed in the Ukrainian intellectual environment of Yelisavetgrad where Narodnik ideals were cherished. The knowledge he acquired in the Progymnasium, self-education and everyday observation of the rural economy transformations in the countryside after the land reform allowed Mykola Levytskyi to apply his theoretical knowledge in practice. Its dominants in the "Yelisavetgrad period" of his life were to establish economic feasibility and necessity of production cooperatives which could be an alternative to peasants' homestead economies under conditions of the capitalist market formation.

The "artels' father" success and failures in cooperative movement creation have been thoroughly analysed, the peasantry public opinion on it has been covered, and estimates of the impact Mykola Levytskyi had on the development of the Ukrainian cooperative movement formation in Central Ukraine at the brink of the $19^{\text {th }}$ and $20^{\text {th }}$ centuries have been provided.

Key words: Mykola Levytskyi, public activity, Ukrainophily, peasantry, production cooperation, cooperative movement, Zlatopol, Yelisavetgrad, Kherson Province, Russian Empire. 
Постановка проблеми та її значення. Соціально-економічні погляди Миколи Левитського вітчизняні дослідники характеризують як ліберально-народницькі [1, с. 125], а його партійну приналежність на момент обрання членом Української Центральної Ради у квітні 1917 року пов'язують із «селянською» партією українських есерів-соціалістів - УПСР, яку він представляв у Малій Раді. 3 листопада 1917 року М. Левитський працював на керівних посадах у Генеральному секретарстві земельних справ урядів Центральної Ради [2, с. 114]. Однак слід звернути увагу той факт, що ідеї соціалізму, які сповідував «артільний батько» у молоді роки, ні на йоту не наблизили його до розуміння специфіки марксизму російського штибу. Споглядальне ставлення російських марксистів до «умов народного життя», чим, зокрема, хибувала політична платформа Г. Плеханова, вирок дрібному господарству в умовах ринкової трансформації економіки, який лідер більшовиків В. Ульянов-Ленін виголосив у праці «Розвиток капіталізму в Росії» (1899 р.), відкидалися М.В. Левитським [3, с. 48]. Він мав тверде переконання, сформоване на основі власного досвіду, у тому, що кооперація була на той час єдино можливою формою організації та убезпечення економічних інтересів дрібного виробника сільськогосподарської продукції - селянина та водночас одним із напрямків розвитку економічних відносин у сільському господарстві Російської імперії доби формування капіталістичних відносин [4, с. 29]. Позицію М. Левитського уточнює аналіз його публічних виступів. Зокрема, долучившись до дискусії з представниками російських марксистів, яка відбулася у Петербурзі 1898 року за ініціативи керівництва «Вільного економічного товариства», Микола Васильович висловив думку, що розуміння проблеми модернізації російського суспільства пореформеної доби полягає у тому, щоб віднайти свій шлях розвитку села, «...міряти цивілізацію (мався на увазі розвиток економічних відносин у сільському господарстві. - Авт.) кількістю ідей, а не витоптаних личаків» [5, с. 40].

Варто вказати на актуальність висновків сучасних учених, які відзначали, що накопичений науковцями масив фактів з історії громадської діяльності Миколи Васильовича не зменшив, а, навпаки, збільшив інтерес до його наукової біографії [6, с. 125-128]. Спираючись на висновки класичних праць Б. Мартоса [7], I. Витановича [8], матеріали новітніх досліджень вітчизняних істориків С. Костика [9], I. Фаренія [10], В. Масненка [11], С. Шкірчака [11], розвідки краєзнавців В. Боська [12], Л. Куценка [13], С. Шевченка [14], а також віднайдені архівні документи й матеріали публікацій про діяльність М. Левитського у місцевій пресі, маємо можливість поглибити розуміння тих процесів, які мали значний вплив на формування суспільно-політичних поглядів українського кооператора у другій половині 1890-х - початку 1900 -х років.

Мета наукового дослідження. Визначити ключові чинники формування світогляду М. Левитського в роки навчання в Златопільській прогімназії; проаналізувати матеріали, які дають змогу дослідити характер взаємовідносин «артільного батька» з відомими представниками українського письменства Л. Косач, І. Франком, І. Тобілевичем; здійснити короткий огляд його кооперативної, громадської та літературно-публіцистичної діяльності у повітовому місті Єлисаветграді зазначеного періоду.

Виклад основного матеріалу. Вихований у родині православного священика на основі шанування традицій «народного життя», юнак обгрунтував ідею самопомочі та реалізації економічних інтересів 80\% українців через створення виробничих об'єднань селянських господарств у формі кооперативних товариств. Погляди М. Левитського у молоді роки формувалися під впливом викладачів Златопільської прогімназії, до якої, згідно із заявою батька, поданою на ім'я інспектора навчального закладу, він був зарахований у серпні 1869 року [15, арк. 525 зв.]. У різний час у прогімназії викладали статистик О. Русов, літератор Г. Грушевський, історик і географ К. Успенський, математик В. Іванов [16, с. 53]. Помітний вплив на гімназиста М. Левитського, за даними краєзнавців, мав учитель латинської мови, «дійсний студент Київського університету Святого Володимира» Гаврило Стрижевський. Його захоплення природою Лісостепу, любов до українства, передалися Миколі Левитському [10, с. 68]. На жаль, про особистість самого Г. Стрижевського історикам відомо надто мало. У віднайденому нами у фондах Державного архіву Кіровоградської області (далі ДАКО) циркулярному листі попечителя Київського освітнього округу, відправленому на службову адресу директора Златопільської прогімназії, повідомлялося, що Г. Стрижевський тривалий час перебував під наглядом адміністрації Київського університету Святого Володимира $з$ тієї причини, що «був діяльною особою та мав негативний вплив на світогляд багатьох своїх товаришів» [17, арк. 5].

Дослідження джерел особового походження та архівних документів, які зберігаються у фондосховищах ДАКО, показало, що М. Левитський напружено займався самоосвітою. На основі засвоєних теоретичних знань у галузі економічної науки він виробив власну світоглядну позицію «практичного соціалізму», яка адаптувала селянське господарство до умов капіталістичних трансформацій на засадах кооперативної праці. У зрілому віці згадував: «Я ще в сьомому класі гімназії обрав собі кооперативний шлях» [Цит. 10, с. 68]. 
Із плином часу практична мета життя й діяльності «артільного батька» не змінювалася. Однак методи іiі реалізації залежали від багатьох причин, зокрема загострення соціально-економічного становища на Півдні України у 1890-х роках. Окрім того, помітний вплив на соціальну сферу буття російської провінції мало посилення визвольного руху в українських землях. Громадсько-політичні настрої у віддаленому від губернського центру повітовому містечку Єлисаветграді у другій половини 1880-1890-х роках, за свідченнями Арсена Тарковського, визначалися активною діяльність загальноросійських партій та організацій народницького спрямування. Серед поширюваної у місті політичної літератури у той час часто зустрічалися видання «Громади» М. Драгоманова, випуски журналу «Вперед» П. Лаврова, які знаходили своїх читачів, зокрема у сільській місцевості [18]. Ідеї «громадівського соціалізму» Михайла Драгоманова мали у Слисаветграді доволі обмежене число прихильників. Лише з появою у місті члена Київської громади Опанаса Михалевича у 1878 році, якого було направленого для підсилення українства, громадівський рух дещо пожвавився. Як непересічна особистість він згуртував навколо себе місцевих чиновників, земців, освітян. Так, відомий український громадський діяч і меценат Свген Чикаленко згадував в одному ряду з І. Тобілевичем, М. Кропивницьким, М. Садовським, які брали активну участь у роботі гуртка О. Михалевича, ім'я «висланого з Московського університету поповича з Александрійського повіту Миколи Левитського». Гуртківці вивчали праці М. Драгоманова, займалися перекладом українською мовою творів А. Сміта, поширювали серед місцевих селян народницьку літературу [19, с. 98].

Краєзнавець Л. Куценко ввів до наукового обігу дані про обговорення на декількох засіданнях гуртка О. Михалевича питань, що стосувалися організації кооперативних об'єднань селянських господарств в Єлисаветградському й Олександрійському повітах Херсонської губернії за участі земського статистика О. Русова, на якому, ймовірно, був присутнім М. Левитський [20, с. 93]. За допомогою таємного інформатора поліція дізналася про склад гуртківців, вивчила характер діяльності кожного учасника. У грудні 1888 року О. Михайлевича та ближнє коло його товаришів за вироком Одеської судової палати було ув'язнено на п'ять років заслання до Іркутської губернії у сфальшований місцевою владою справі єлисаветградців як «організаторів державного перевороту». Свого часу, вказуючи на цей прикрий факт, дослідниця Н. Бракер відзначала, що гуртківців, головним чином, звинувачували у поширенні серед населення забороненої та дозволеної літератури на «малороссийском наречии». Очевидно, слідчими було взято до уваги звернення О. Михайлевича та його товаришів у 1880 році до російського літератора, співробітника журналу «Вісник Свропи» О. Пипіна з проханням обговорити на сторінках цього ж видання питання про становище української мови у Російській імперії [21].

Як свідчать матеріали місцевої преси, після повернення в 1892 році із сибірського заслання до Єлисаветграда О. Михайлевич не відмовився від своїх життєвих принципів та переконань, активної просвітницької та благодійницької діяльності [22]. Дослідник історії міста Єлисаветграда дореволюційної доби Сергій Шевченко зазначав, що О. Михайлевич, який користувався великим авторитетом у колах української народницької інтелігенції, мав у той час значний вплив на формування поглядів відомих в Україні громадських діячів: М. Лащенка, Й. Шевченка, Є. Чикаленка, М. Левитського, О. Волошина, А. Грабенка, Т. Василевського, Д. Марковича, В. Менчиця, О. Тарковського [23, с. 28].

Діяльність М. Левитського не обмежувалася участю у народницькому гуртку О. Михайлевича. Так, один з організаторів Революційної Української партії (РУП) Ю. Коллард згадував про його активну участь у публічних заходах, які проводила Студентська громада міста Харкова. Зокрема, наприкінці 1898 - у першій половині 1899 року Микола Левитський неодноразово брав участь у засіданнях Харківської громади. Він розповідав громадівцям про труднощі створення кооперативів на Херсонщині, поширював у студентському середовищі ідеї заснування на селі національних організацій. У своїх виступах М. Левитський характеризував кооперативну артіль як українську національну економічну структуру, яка водночас об'єднує («гуртом батька бити легше») та захищає селянина-українця від проявів експлуатації [24, с. 52].

Не втратила актуальності полеміка, пов'язана з висвітленням реакції урядових та політичних кіл Російської імперії на створення кооперативів в Україні. Відомо, що вона знайшла відображення на сторінках столичної (петербурзької) преси 1890-х років як «єлисаветградська артільна епопея Левитського». Розбіжність позицій їі учасників пояснюється не лише значенням земельного, селянського питання, а й ставленням до кооперативного руху в Наддніпрянській Україні. Увага авторів акцентувалася здебільшого на оцінках кооперативної праці М. Левитського. Зазначалися здобутки й невдачі «артільного батька» у створенні виробничих кооперативних об'єднань, розкривалося ставлення до цієї справи селян [25]. Однак за межами дискусії залишився засвідчений фактом появи чисельних публікацій організований на Півдні Росії кооперативний рух, який мав значний суспільний резонанс, 
привернув увагу видатних українців. Сам Микола Васильович у 1913 р. залишив теплі спогади про відвідини Лесею Українкою північних повітів Херсонщини. Зокрема, він детально описав ії приїзд до села Аджамки, де успішно діяли селянські кооперативні об'єднання. Наголосив на тому, «...3 яким щирим і живим зацікавленням віднеслася Леся Українка до спілкової справи, як вона розпитувала про господарство й життя спілок узагалі і цікавилася подробицями спілкової організації» [26, арк. 1]. М.В. Левитський зазначав, що «симпатії до кооперації - це дуже характерна і відрадна риса душі наших видатних людей» [26, арк. 2]. Серед відомих прихильників кооперативної справи, «...які дуже цікавилися і завжди з великою симпатією відносилися до кооперації», він називає імена відомих українців, що «словом й ділом» підтримували його у найскрутніші часи в нелегкій роботі: М. Кропивницького, І. Карпенко-Карого, Т. Рильського, Б. Грінченка, В. Антоновича, М. Лисенка і М. Коцюбинського [26, арк. 2]. У зазначеному контексті нового звучання набувають системні дослідження епістолярної спадщини М. Коцюбинського, І. Франка, Л. Українки. Зокрема, у згадуваному нами дописі краєзнавця В. Боська, а також фахових публікаціях істориків С. Шевченка [27] та Є. Босої [28] містяться вибіркові дані стосовно реакції названих осіб на практичну діяльність Миколи Васильовича Левитського. На нашу думку, ретельне вивчення матеріалів, акумульованих в особовому фонді М.В. Левитського № 327 Інституту рукопису Національної бібліотеки імені В. Вернадського, який налічує 2117 одиниць зберігання, а також фондів обласних архівів, дасть змогу розширити коло адресатів «артільного батька» [29]. Дослідження архівної спадщини М. Левитського, здійснене В. Вовченко, засвідчило, що серед епістолярію кооператора згадуються листи до таких відомих в Україні громадських діячів, як М. Ковалевський, В. Дурдуківський, М. Токаревський, В. Антонович, Є. Максимов, В. Краснов, О. Амчиславська, М. Слабченко, К. Скаржинська. На жаль, листування М. Левитського із зарубіжними діячами та кооперативними установами були назавжди втрачені під час пограбування його будинку 1922 року в м. Слисаветграді [30, с. 9].

На окрему увагу заслуговує висвітлення діяльності «присяжного-повіренного М.В. Левитського» у якості «дійсного члена Єлисаветградського Товариства поширення грамотності й ремесел». Це громадське об'єднання, створене 1873 року, утримувало на балансі професійно-освітнє училище з жіночим і чоловічим відділеннями, Народну бібліотеку (з 1895 р.), володіло дарованими меценатами будівлями й літнім садом «Альгамбра». Товариство формувало свою матеріальну базу через отримання дарчих та заповітів на володіння нерухомим майном. Його казна поповнювалася завдяки пожертвуванням заможних містян, за рахунок відсотків від процентних ставок грошових переказів благодійників, а також придбання ними лотерейних білетів, виручки від організації виставок, читання лекцій, інших видів громадської діяльності [31, с. 6]. Керівний орган - Рада Товариства, який переобирався щорічно, очолювався бургомістром, іншими представниками міської влади або відомими підприємцями, землевласниками. Наприклад, у звітний період 1894-1895 рр. список почесних членів Ради Товариства поширення грамотності й ремесел очолював міський голова Слисаветграда Олександр Пашутін. До складу Ради неодноразово обиралися почесний громадянин міста Єлисаветграда підприємець Роберт Ельворті, освітянин, багаторічний директор Єлисаветградського ремісничо-грамотного училища Микола Федоровський, інші відомі містянам особистості [32, с. 91, 143]. Збережені у фонді ДАКО документи висвітлюють створення та функціювання Слисаветградського товариства поширення грамотності і ремесел. Аналіз текстів щорічних звітів, фінансових документів, протоколів засідань Ради уможливлює вивчення причетності М. Левитського до цієї громадської організації. Зокрема, у 1895 році у складі Тимчасової комісії він здійснював аналіз матеріально-фінансового стану забезпечення навчально-виховного процесу в Слисаветградському ремісничо-грамотному училищі та брав участь у засіданнях тимчасових комісій. Опублікований у місцевій пресі звіт громадської комісії про занедбаний стан будівель, розміщених на території міського парку «Альгамбра», переданого купцем С. Остроуховим у користування ремісничо-грамотному училищу, свідчить про принципову позицію М. Левитського, інших членів названої комісії у розв'язанні питання, пов'язаного з використанням купецького спадку на користь громади міста [33]. Оскільки Микола Васильович був у складі опікунської ради згадуваного училища, у 1890-ті роки його нерідко залучали до проведення експертиз технічного забезпечення навчальних майстерень, з'ясування причин невиплати заробітної платні робітникам та майстрам закладу, розв'язання інших проблем [34, с. 74, 155]. За даними архівних документів, у жовтні 1904 року М. Левитський в останнє перебував у складі дійсних членів Товариства, обраних на щорічний період його діяльності $[35$, с. 5$]$.

Невгамовна душа Миколи Васильовича знаходила відпочинок у віршованих творах, темою яких була доля України. Вони публікувалися у різний час в єлисаветградській друкарні братів Шполянських, 
київських друкарнях у вигляді «кишенькових книжечок», які автор роздавав друзям. Зазначимо, що окремі зразки поетичного доробку «артільного батька» аналізувалися дослідниками, але стверджувати, що ця тема $€$ «остаточно вичерпаною», здається, немає підстав. На нашу думку, призабуті науковцями прозові твори М. Левитського. У цьому зв'язку пригадаємо, що Олександр Семененко, який знав Миколу Васильовича зі студентських років, писав, що «...Левитський був ... символом народолюбного, ідеалістичного, чесного світу» [36, с. 25]. Саме такий образ «артільного батька» формують спостереження «народного життя», що видавалися Миколою Левитським у місцевій газеті «Голос Юга». Окремі з них мали громадське, педагогічно-виховне спрямування. Зокрема, у статті «До майбутнього студентського вечора», опублікованій у грудні 1915 року, автором мовилося про нехтування у студентському середовищі повітового міста Слисаветграда українською мовою, культурою, історією. У м'якій формі, але рішуче й послідовно, М. Левитський обстоював право місцевого селянства на створення кооперативних об'єднань, проводив просвітницьку роботу серед молоді, публікував витримки з текстів історичних документів про колонізацію Російською імперією козацьких земель т. зв. «дикого поля» [37].

Висновки і перспективи дослідження проблеми. Аналіз здобутків вітчизняних науковців, вивчення змісту архівних документів та матеріалів періодики дає змогу стверджувати, що суспільнополітичні погляди М. Левитського формувалися у середовищі, де панували народницькі ідеали. Знання, здобуті в гімназії, самоосвіта юнака, а особливо щоденне спостереження за станом селянського господарства у пореформеному українському селі, дали поштовх до практичного застосування ним теоретичних знань. Домінантою професійної та громадської діяльності М. Левитського в «єлисаветградський період» $є$ обгрунтування економічної доцільності і необхідності створення місцевими селянами виробничих кооперативів із метою протистояння експлуатації селянського дрібного господарства в умовах розвитку капіталістичних відносин на Півдні України, зокрема Херсонській та Катеринославській губерніях.

Участь М. Левитського в студентському русі, громадській роботі справила великий вплив на його свідомість. Микола Васильович не відмовився від планів поліпшення соціально-економічного становища українського селянства, які зародилися ще у гімназійні роки, але з плином часу та теоретичним опрацюванням досвіду доповнив останні практичними викладками, низкою принципових положень про перспективи розбудови української кооперації.

\section{Література:}

1. Костик Є.П. Дискусії навколо діяльності М.В. Левитського. Украӥнський селянин. 2008. Вип. 11. С. 125-128.

2. Верстюк В., Осташко Т. Діячі Української Центральної Ради. Біографічний довідник. Київ : Б. в., 1998. 254 с.

1. Фареній І.А. Політичні погляди та «закон історичної перспективи» Миколи Левитського. Вісник Черкаського університету. Серія «Історичні науки». 2010. Вип. 192. С. 47-52.

2. Фареній І.А. Соціалізм і кооперація в поглядах «артільного батька» Миколи Левитського. Вісник Черкаського університету. Серія «Історичні науки». 2015. Вип. 29(362). С. 28-33.

3. Гелей С. Кооперація і національне відродження української державності Вісник НТШ : інформаційне видання / Світова рада наукових товариств імені Шевченка. Львів, 2013. Число 49. С. 40.

4. Костик Є.П. Дискусії навколо діяльності М.В. Левитського. Украӥнський селянин. 2008. Вип. 11. С. 125-128.

5. Мартос Б. Теорія кооперації. На правах рукопису. Падебради, 1923. 246 с.

6. Витанович І. Історія українського кооперативного руху. Нью-Йорк : Б. в., 1964. 624 с.

7. Костик Є.П. Микола Левитський - організатор кооперативного руху Украӥнський селянин. 2002. Вип. 5. С. 48-51.

8. Фареній І.А. «Артільний батько» Микола Левитський: молоді роки Вісник Черкаського університету. Серія «Iсторичні науки». 2011. Вип. 212. С. 67-73.

9. Шкірчак С. Кооперативний рух як елемент громадянського суспільства в історії української суспільно-політичної думки першої чверті XX ст. Українська національна ідея: реалії та перспективи розвитку. 2013. Вип. 25. С. $49-54$.

10. Босько В. Слисаведградська епопея «артільного батька». Народне слово. 1998. 21, 23,28 липня.

11. Куценко Л. «Народу самосійні діти...» Українська доля дикого поля. Кіровоград : Б. в., 2005. С. 92-98.

12. Шевченко С. Єлисаветградський період у життєпису родини Шульгиних (1894-1899). Наукові записки. Серія «Історичні науки». 2010. Вип. 13. С. 372-379.

13. Державний архів Кіровоградської області. Ф. 499. Оп. 1. Спр. 52.525 арк. зв.

14. Затока В.В. Златопільська гімназія. Сторінки історії. Кіровоград ; РВГ ІЦ КДПУ, 1998. 130 с.

15. Державний архів Кіровоградської області. Ф. 499. Оп. 1. Спр. 43.5 арк.

16. Тарковский А. Очерк революционного движения 80-х годов в Елисаветграде. Єлисавет. 1992. 16 вересня.

17. Чикаленко Є. Спогади. 1861-1907. Нью-Йорк : Українська Вільна Академія наук у США, 1955. 504 с.

18. Куценко Л. «Народу самосійні діти». Українська доля «дикого поля». Кіровоград : Б. в., 2005. 119 с.

19. Бракер Н. Опанас Іванович Михалевич (1848-1925 рр.). Слисавет. 1992. 8 липня.

20. Ведомости Елисаветградскогогородского общественнаго управления. 26 февраля 1895 г. 
21. Шевченко С.І. Шульгини: Інгульська сторінка. Кіровоград : Імекс-ЛТД, 2013. 145 с.

22. Коллард Ю. Спогади юнацьких днів 1898-1906. Торонто : Срібна сурма, 1972. 223 с.

23. Босько В. Слисаведградська епопея артільного батька. Народне слово. 1998. 21, 23, 28 липня.

24. Державний архів Кіровоградської області. ДАКО ДІФ. Колекція спогадів. Інв. № 622. 1-2 арк.

25. Шевченко С. «Інтересна звістка Каменяреві» від «артільного батька». Народне слово. 2006. 1 серпня.

26. Боса Є. Леся Українка і «артільний батько». Народне слово. 2009. 12 березня.

27. Інститут рукопису Національної бібліотеки України імені В.І. Вернадського (ІР НБУВ). Ф. 327.

28. Вовченко В.Б. Архівна спадщина кооператора, державного і громадського діяча М.В. Левитського (1859-1936): історія, реконструкція, зміст : автореф. дис. ... канд. іст. наук. Київ, 2007. 19 с.

29. Державний архів Кіровоградської області. Ф. 56. Оп. 1. Спр. 9, 6 арк.

30. Державний архів Кіровоградської області. Ф. 56. Оп. . Спр. 9. 91, 143 арк.

31. Ведомости Елисаветградского городского общественнаго управления. 1895. 26 февраля.

32. Державний архів Кіровоградської області. Ф. 56. Оп. 1. Спр. 9. 74, 155 арк.

33. Державний архів Кіровоградської області. Ф. 56. Оп. 1. Спр. 15. 5 арк.

34. Семененко О. Харків, Харків ... Харків - Нью-Йорк : Березіль, 1992. 240 с.

35. Голос Юга: Газета политическая, экономическая и литературная. 195. № 302. 